\title{
WIEK EMERYTALNY LUDNOŚCI W PAŃSTWACH UNII EUROPEJSKIEJ W KONTEKŚCIE OBCIĄŻENIA EKONOMICZNEGO I PRZECIĘTNEGO TRWANIA ŻYCIA
}

\section{WSTEPP}

W ostatnim okresie w wielu europejskich krajach odbywała się dyskusja na temat wydłużenia lat aktywności zawodowej ludności przez między innymi przesunięcie granicy wieku, po osiągnięciu którego można przechodzić na emeryturę. Dyskusja ta pojawiła się w ostatnim okresie w związku z kryzysem finansów publicznych tych państw związanym z dynamicznym wzrostem ich zadłużenia. Jednakże główne przyczyny konieczności wydłużania wieku produkcyjnego ludności sa daleko głębsze i wynikaja przede wszystkim ze współcześnie obserwowanych procesów demograficznych. W wyniku tych procesów populacje krajów rozwiniętych - w związku ze spadkiem dzietności oraz wydłużaniem się życia ludzkiego - starzeją się. Rośnie obciążenie ludności w wieku produkcyjnym ludnością w wieku nieprodukcyjnym, w szczególności ta, która swój okres aktywności zawodowej ma już za sobą. W wielu państwach w ostatnim okresie rozpoczął się proces stopniowego podwyższania ustawowego wieku, po którym można przechodzić na emeryturę. W niniejszym artykule zaproponowano metodę pozwalająca wyznaczyć postulowaną minimalną górną granicę wieku produkcyjnego, po której ludność w danym okresie mogłaby najwcześniej przechodzić na emeryturę. Metoda ta wykorzystuje pojęcia demografii potencjalnej, której powstanie datuje się na lata czterdzieste ubiegłego wieku ${ }^{1}$. Jej głównym założeniem jest postulat, aby dla całej populacji łączna liczba lat do przeżycia w okresie życia w wieku nieprodukcyjnym nie była wyższa niż łączna liczba lat do przeżycia $\mathrm{w}$ okresie życia $\mathrm{w}$ wieku produkcyjnym. Metoda ta uwzględnia w swoich założeniach przeciętne dalsze trwanie życia wraz ze strukturą ludności według wieku. Jej wyniki porównano dla państw Unii Europejskiej.

\section{METODA}

Każda populacja ma określony potencjał życiowy, czyli łączną liczbę lat, jaką na dany moment czasu ma jeszcze do przeżycia. Całkowity potencjał życiowy danej populacji można wyznaczyć, posiadając szczegółowe dane na temat

${ }^{1}$ E. Vielrose, Zarys demografii potencjalnej, Warszawa 1958, s. 15. 
struktury ludności według poszczególnych rocznych grup wieku oraz pełne tablice trwania życia za pomocą wzoru:

$$
V(0, \omega ; 0, \omega)=\sum_{0}^{\omega-1} P_{x} \cdot \frac{e_{x}+e_{x+1}}{2},
$$

gdzie: $\quad V(0, \omega ; 0, \omega)$ - potencjał grupy osób w wieku od 0 do $\omega$ lat na okres życia od 0 do $\omega$ lat,

$\omega$ - najwyższy wiek $\mathrm{w}$ tablicy wymieralności, w którym liczba dożywających osób staje się równa zeru,

$P_{x}$ - średnia liczba ludności dla danego rocznika wieku,

$e_{x}$ - przeciętne dalsze trwanie życia dla danego rocznika wieku.

Potencjał grupy osób w wieku od $m$ do $M$ lat na okres życia od $n$ do $N$ lat wyznacza się za pomocą wzoru:

$$
V(m, M ; n, N)=\left(l_{n} e_{n}-l_{N} e_{N}\right) \cdot \sum_{m}^{M-1} \frac{P_{x}}{0,5\left(l_{x}+l_{x+1}\right)},
$$

gdzie: $l_{x}$ - liczba osób dożywających określonej liczby lat z tablic trwania życia.

Za pomocą wzoru (2) można obliczyć część całkowitego potencjału życiowego, która zrealizuje się w wieku przedprodukcyjnym, produkcyjnym i poprodukcyjnym. Relację pomiędzy potencjałami życiowymi ludności na okresy życia w wieku produkcyjnym a potencjałami w wieku nieprodukcyjnym autor oznacza jako potencjalny wskaźnik obciążenia demograficznego ${ }^{2}$, który wskazuje, jaka część lat do przeżycia w okresie życia w wieku produkcyjnym stanowią lata do przeżycia $\mathrm{w}$ okresie życia $\mathrm{w}$ wieku nieprodukcyjnym.

Postulowana minimalna górna granica wieku produkcyjnego oznacza wiek, dla którego potencjał życiowy ludności do przeżycia w okresie życia w wieku nieprodukcyjnym będzie równy potencjałowi życiowemu ludności do przeżycia w okresie życia w wieku produkcyjnym. W takim wypadku potencjalny współczynnik obciążenia demograficznego byłby równy jedności. Postulat ten przyjmując dolną granicę wieku produkcyjnego równą 20 lat - można zapisać za pomocą wzorów demografii potencjalnej:

$$
\begin{gathered}
\left(l_{20} e_{20}-l_{z} e_{z}\right) \cdot \sum_{0}^{\omega-1} \frac{P_{x}}{0,5\left(l_{x}+l_{x+1}\right)}=\left(l_{0} e_{0}-l_{20} e_{20}\right) \cdot \sum_{0}^{\omega-1} \frac{P_{x}}{0,5\left(l_{x}+l_{x+1}\right)}+ \\
\quad+l_{z} e_{z} \cdot \sum_{0}^{\omega-1} \frac{P_{x}}{0,5\left(l_{x}+l_{x+1}\right)},
\end{gathered}
$$

gdzie: $z$ - postulowana minimalna górna granica wieku produkcyjnego.

\footnotetext{
${ }^{2}$ R. Murkowski, Ocena obciażenia demograficznego ludności Polski na lata 2010-2025, w: Modelowanie $i$ prognozowanie gospodarki narodowej, Prace i Materiały Wydziału Zarządzania Uniwersytetu Gdańskiego, Sopot 2011, s. 435-452; idem, Obciażenie demograficzne w Polsce w latach 1991-2008, ,Wiadomości Statystyczne” 2012, nr 5.
} 
Państwa, dla których postulowana minimalna górna granica wieku produkcyjnego przyjmować będzie najwyższe wartości, będą cechować się długim przeciętnym dalszym trwaniem życia oraz wysokim wskaźnikiem obciążenia demograficznego ludności $\mathrm{w}$ wieku produkcyjnym ludnością $\mathrm{w}$ wieku nieprodukcyjnym - w szczególności ludnością w wieku poprodukcyjnym.

\section{PRZECIE}

Europa, w tym Unia Europejska, jest jednym z obszarów świata, gdzie ludność ma wysoką szansę dożycia wieku podeszłego. W 2009 r. najdłużej w UE żyły kobiety urodzone we Francji, gdzie nowo urodzona dziewczynka miała przed sobą przeciętnie aż 85 lat do przeżycia. Do państw, gdzie przeciętna długość życia kobiety była wyższa niż 84 lata, należały również Hiszpania i Włochy. Natomiast w przypadku mężczyzn najdłużej żyli Szwedzi, którzy w 2009 r. mieli przeciętnie aż 79,4 roku do przeżycia. Mężczyzna ze Szwecji żył w 2009 r. dłużej niż przeciętna kobieta z takich państw, jak Litwa, Łotwa, Rumunia, Słowacja czy Węgry. Do państw UE, w których przeciętne dalsze trwanie życia mężczyzn przekraczało 78 lat, w 2009 r. należały Holandia, Hiszpania, Cypr, Wielka Brytania, Włochy, Luksemburg i Francja.

\section{Rysunek 1}

Przeciętne dalsze trwanie życia kobiet w 2009 r.

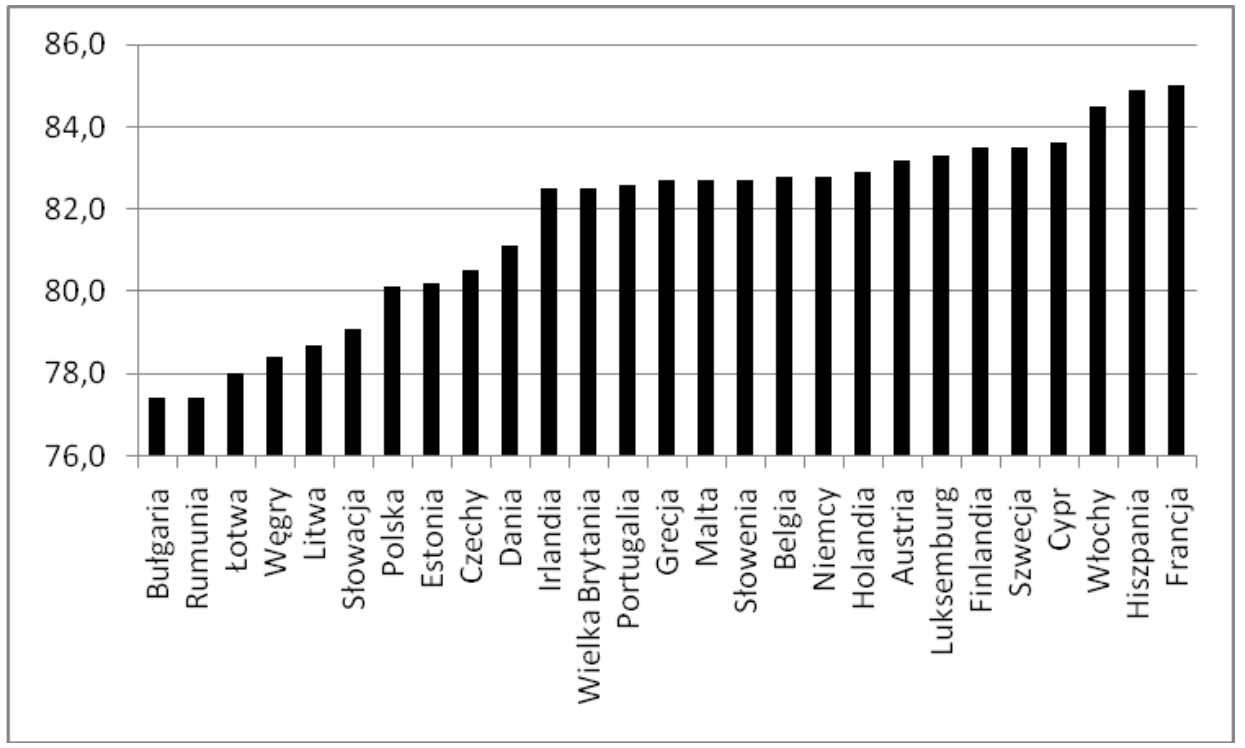

Źródło: opracowanie własne na podstawie danych Eurostat. 
Rysunek 2

Przeciętne dalsze trwanie życia mężczyzn w 2009 r.

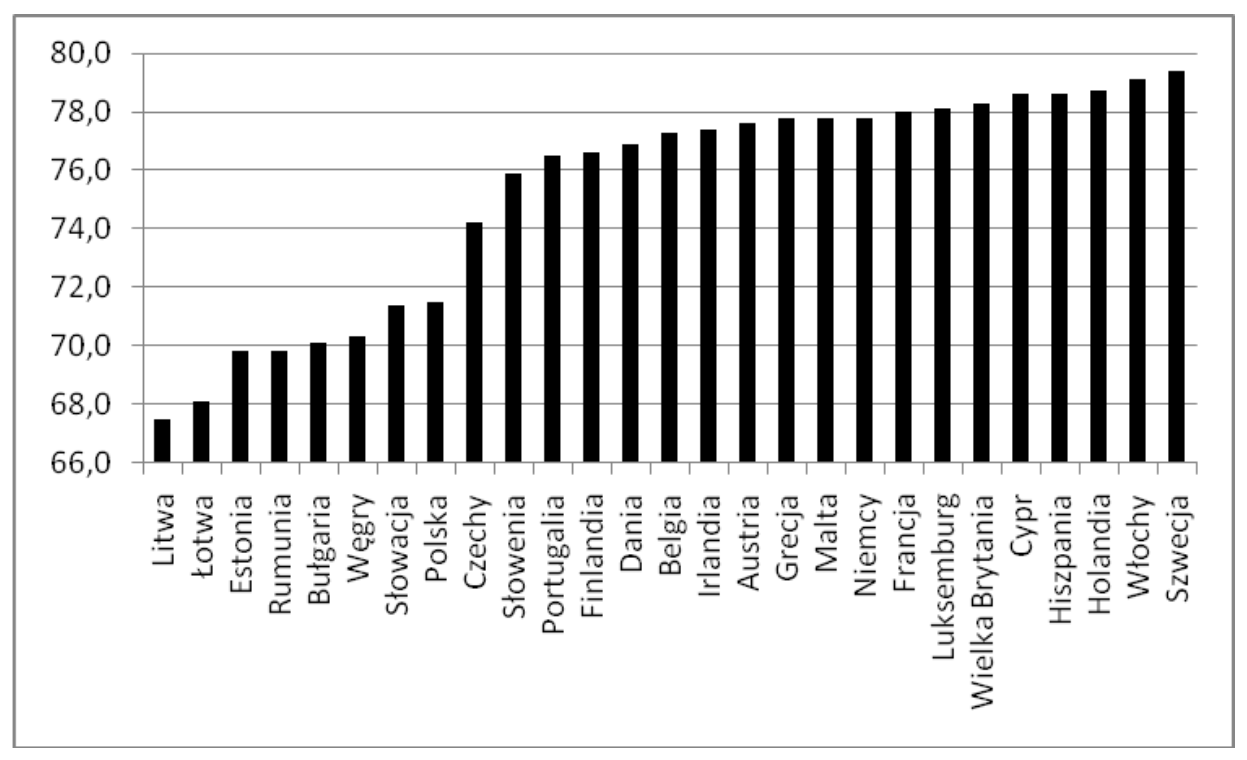

Źródło: opracowanie własne na podstawie danych Eurostat.

Kraje Europy Środkowej oraz kraje bałtyckie należały w UE do państw, w których ludność żyła najkrócej. W 2009 r. noworodek płci żeńskiej urodzony w Bułgarii i Rumunii miał przed sobą do przeżycia tylko 77,4 roku - najmniej ze wszystkich członków UE. Przeciętne dalsze trwanie życia kobiety było w 2009 r. poniżej 70 lat w takich państwach, jak Bułgaria, Rumunia, Litwa, Łotwa, Estonia, Węgry i Słowacja. Do państw UE, w których przeciętne dalsze trwanie życia mężczyzn było najkrótsze, należały wszystkie kraje bałtyckie. W 2009 r. przeciętny Litwin miał przed soba do przeżycia przeciętnie tylko 67,5 rokunajmniej w całej UE. Przeciętne dalsze trwanie życia mężczyzn było w 2009 r. poniżej 70 lat w takich państwach, jak Litwa, Estonia, Łotwa, Bułgaria, Rumunia, Polska, Węgry, Słowacja oraz Czechy.

Terytorialne zróżnicowanie $\mathrm{w}$ przeciętnym dalszym trwaniu życia wśród państw wchodzących w skład UE wykazywało tendencję malejącą. Różnica między długością życia w państwie UE, gdzie się żyło się najdłużej i najkrócej, zmniejszyła się z 14,8 roku (1995 r.) do 11,9 (2009 r.) dla mężczyzn oraz z 8,7 roku (1995 r.) do 7,6 (2009 r.) dla kobiet. W okresie ostatnich piętnastu lat największy wzrost długości przeciętnego dalszego trwania życia mężczyzn i kobiet wystapił w Estonii (8,5 roku w przypadku mężczyzn i 6 lat - kobiet), natomiast najmniejszy w przypadku mężczyzn w Bułgarii (wzrost o mniej niż 3 lata) oraz kobiet ze Szwecji (wzrost o mniej niż 2 lata). 


\section{OBCIĄŻENIE DEMOGRAFICZNE LUDNOŚCI}

Jedną z syntetycznych miar obrazujących strukturę ludności według wieku z uwzględnieniem jej podziału na osoby w wieku produkcyjnym i nieprodukcyjnym jest współczynnik obciążenia demograficznego, który oznacza relację pomiędzy liczbą ludności w wieku nieprodukcyjnym a liczbą ludności w wieku produkcyjnym. Współczynnik ten pokazuje, ile osób w wieku nieprodukcyjnym przypada na 100 lub 1000 osób w wieku produkcyjnym. Przy obliczeniach wartości tego współczynnika za wiek produkcyjny przyjęto okres życia od 20 do 60 lat.

Rysunek 3

Współczynnik obciążenia demograficznego w 2009 r.

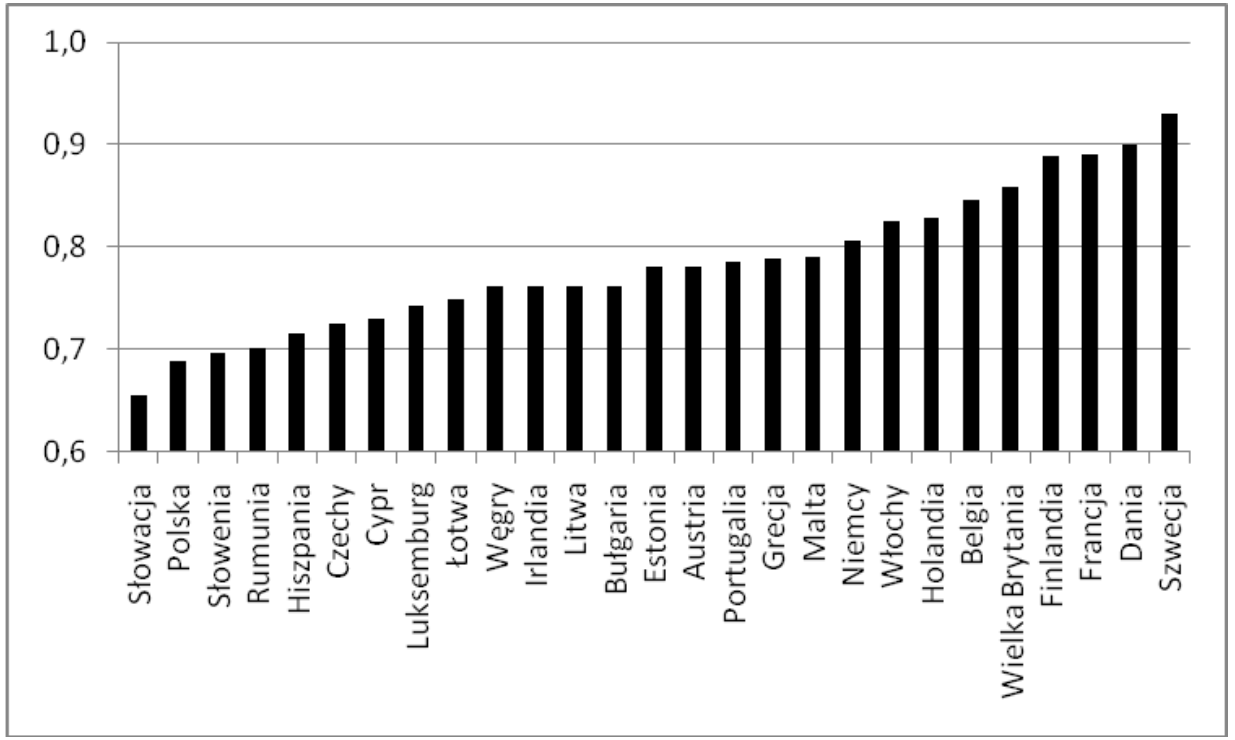

Źródło: opracowanie własne na podstawie danych Eurostat.

W latach 70. ubiegłego wieku $\mathrm{w}$ wielu krajach obserwowany od końca II wojny światowej wzrost obciążenia ludności w wieku produkcyjnym ludnością w wieku nieprodukcyjnym osiągnął najwyższe wartości (por. rysunek 4). Wartości współczynnika obciążenia demograficznego były wtedy w niektórych krajach europejskich wyższe od jedności, co oznacza, że żyło w tych państwach więcej osób w wieku nieprodukcyjnym niż w wieku produkcyjnym. Zasadniczym powodem takiego stanu była duża liczba osób w wieku przedprodukcyjnym wynikająca $\mathrm{z}$ większej liczby urodzeń. W kolejnych latach obciążenie ludności $\mathrm{w}$ wieku produkcyjnym ludnościa $\mathrm{w}$ wieku nieprodukcyjnym zmniejszało się $\mathrm{w}$ związku $\mathrm{z}$ osiagganiem wieku produkcyjnego przez generacje wyżów 


\section{Rysunek 4}

Współczynnik obciążenia demograficznego w wybranych państwach

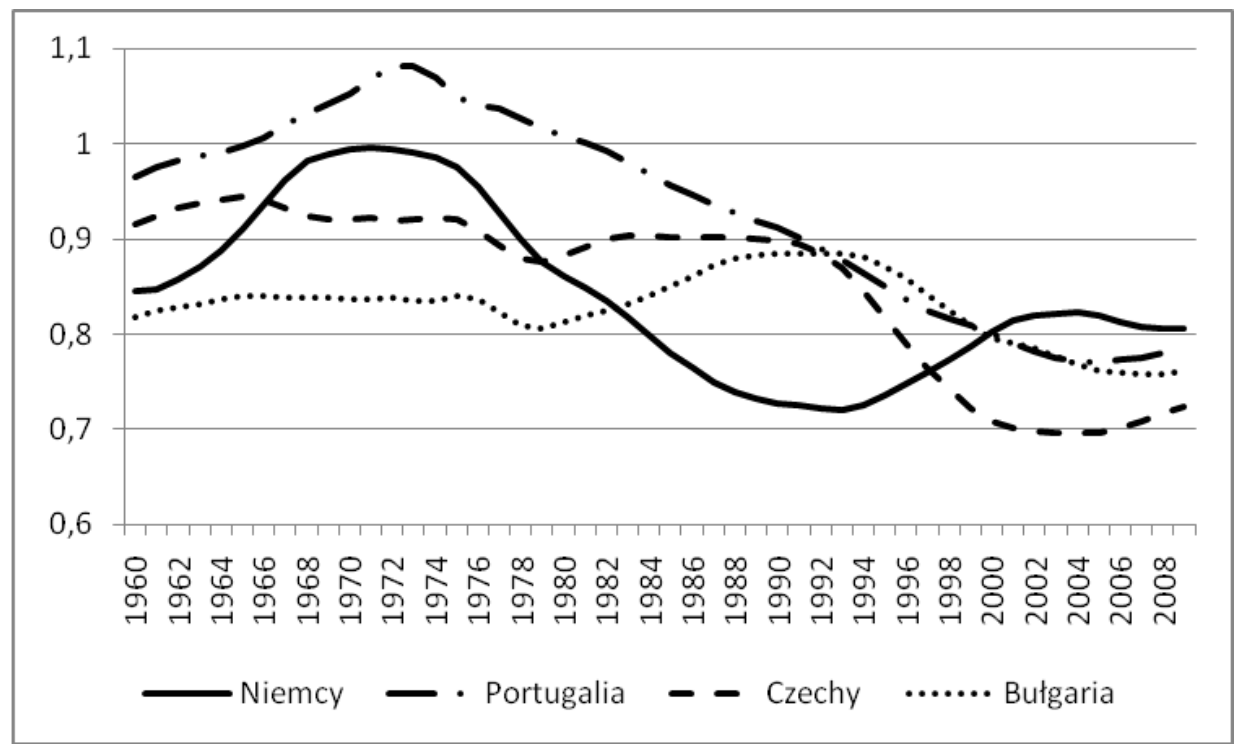

Źródło: opracowanie własne na podstawie danych Eurostat.

demograficznych. W ostatnich latach w wielu krajach europejskich wystapiło bądź wystapi zjawisko wzrostu klasycznego współczynnik obciążenia demograficznego. Jednakże jego główną przyczyną będzie wzrost obciążenia ludności $\mathrm{w}$ wieku produkcyjnym ludnością $\mathrm{w}$ wieku poprodukcyjnym, a nie - jak w latach 60. i 70. - ludnością w wieku przedprodukcyjnym. Zjawisko to nasili się, kiedy wiek poprodukcyjny zaczną osiagać roczniki wyżów demograficznych z przełomu lat 60. i 70., a wiek produkcyjny zaczną osiagać roczniki niżów demograficznych z lat 90.

W 2009 r. w Szwecji na 1000 osób w wieku produkcyjnym przypadało 930 osób w wieku nieprodukcyjnym - najwięcej w całej UE. Wysokie obciążenie ludności będącej $\mathrm{w}$ wieku produkcyjnym ludnością $\mathrm{w}$ wieku nieprodukcyjnym wśród państw UE występowało również w Danii, Francji oraz Finlandii - gdzie ludność w wieku nieprodukcyjnym stanowiła w 2009 r. około 90\% ludności $\mathrm{w}$ wieku produkcyjnym. Natomiast najniższe obciążenie ludności w wieku produkcyjnym ludnościa w wieku nieprodukcyjnym wystąpiło w 2009 r. na Słowacji, gdzie na 1000 osób w wieku produkcyjnym przypadało 655 osób w wieku nieprodukcyjnym. Do państw, w których współczynnik obciazzenia demograficznego był niższy od 0,7, należały w 2009 r. jeszcze Polska oraz Słowenia.

Obciążenie ludności w wieku produkcyjnym ludnością w wieku nieprodukcyjnym było wśród państw UE zawsze wyższe dla kobiet niż dla mężczyzn. Najmniejsza różnica w klasycznym obciążeniu demograficznym pomiędzy popu- 
lacją kobiet i mężczyzn wystąpiła w Irlandii - kraj ten charakteryzuje się relatywnie małą różnica pomiędzy długością przeciętnego trwania życia kobiet i mężczyzn oraz względnie młodą populacją. Natomiast do państwa UE, w których zróżnicowanie obciążenia demograficznego ze względu na płeć było w 2009 r. najwyższe, należały takie kraje, jak Łotwa, Estonia, Słowenia i Litwa. $\mathrm{Sa}$ to państwa, w których notuje się względnie dużą różnicę pomiędzy przeciętnym dalszym trwaniem życia kobiet a mężczyzn ${ }^{3}$, w wyniku czego znacznie więcej kobiet niż mężczyzn dożywa wieku poprodukcyjnego.

\section{POSTULOWANA MINIMALNA GÓRNA GRANICA WIEKU PRODUKCYJNEGO}

W ubezpieczeniu społecznym prawo do otrzymania świadczenia emerytalnego przysługuje po osiągnięciu ustalonego wieku. W poszczególnych krajach wiek ten jest ustalany różnie w zależności od wielu czynników, w tym między innymi sytuacji demograficznej, zdrowotnej, politycznej, gospodarczej i społecznej. Nie umniejszając roli każdego z tych czynników, wydaje się, że w ostatnim okresie zasadniczy wpływ na kształtowanie wieku, po osiagnięciu którego nabywa się prawo do świadczenia emerytalnego, ma czynnik demograficzny. Starzenie się społeczeństw spowodowane wydłużaniem się życia ludzkiego oraz spadkiem dzietności powoduje szereg problemów przede wszystkim o charakterze ekonomicznym, co powoduje potrzebę podwyższania wieku emerytalnego, $\mathrm{z}$ jakim mamy do czynienia już w niektórych państwach od końca lat 70 . ubiegłego stulecia ${ }^{4}$. W tej części artykułu porównano dla państw Unii Europejskiej wyniki zaproponowanej przez autora metody wyznaczającej postulowaną minimalną górną granicę wieku produkcyjnego, po której ludność w danym okresie mogłaby najwcześniej przechodzić na emeryturę. Metoda ta uwzględnia w swoich założeniach długość trwania życia oraz strukturę ludności według wieku. Jej podstawowym założeniem jest postulat, aby populacja nie miała do przeżycia więcej lat $\mathrm{w}$ wieku nieprodukcyjnym niż $\mathrm{w}$ wieku produkcyjnym. Wychodząc $\mathrm{z}$ tego założenia, można oszacować - stosując metody wypracowane przez demografię potencjalna - górna granicę wieku produkcyjnego, dla której zachodzi równość potencjału życiowego do przeżycia przez ludność $\mathrm{w}$ wieku produkcyjnym i nieprodukcyjnym, zakładając jako dolna granicę wieku produkcyjnego - 20 lat. Tak wyznaczony wiek oznaczyć można jako postulowaną minimalna górną granicę wieku produkcyjnego. W związku z tym, że wyniki zaproponowanej metody sugerowałyby wyższą górną granicę wieku produkcyjnego dla kobiet niż dla mężczyzn - co jest sprzeczne $\mathrm{z}$ rozwiązaniami aktualnie obowiązującymi $\mathrm{w}$ funkcjonujących systemach emerytalnych - autor rozważa tylko jej wyniki dla obu płci łącznie. Miara ta może także służyć jako syntetyczny miernik procesu starzenia się populacji,

${ }^{3}$ D. A. Glei, S. Horiuchi, The Narrowing Sex Differential in Life Expectancy in High-Income Populations: Effects of Differences in the Age Pattern of Mortality, „Population Studies” 61, 2007, nr 2; F. Nault, Narrowing Mortality Gaps, 1978 to 1995, „Health Reports” 9, 1997, nr 1, s. 35-40.

${ }^{4}$ W. Muszalski, Przemiany wieku emerytalnego, „Polityka Społeczna” 2009, nr 3, s. 7-11. 
a jej niewątpliwą zaletą jest uwzględnianie jednocześnie struktury ludności według wieku wraz z przeciętnym dalszym trwaniem życia poszczególnych osób w określonym wieku.

Tabela 1

Postulowana minimalna górna granica wieku produkcyjnego

\begin{tabular}{|l|l|l|l|l|l|l|l|l|}
\hline Wyszczególnienie & $\mathbf{2 0 0 0}$ & $\mathbf{2 0 0 9}$ & Wyszczególnienie & $\mathbf{2 0 0 0}$ & $\mathbf{2 0 0 9}$ & Wyszczególnienie & $\mathbf{2 0 0 0}$ & $\mathbf{2 0 0 9}$ \\
\hline Austria & 60,6 & 62,2 & Grecja & 60,3 & 62,4 & Polska & 57,7 & 59,5 \\
\hline Belgia & 60,6 & 62,1 & Hiszpania & 60,9 & 62,7 & Portugalia & 60,0 & 61,9 \\
\hline Bułgaria & 57,7 & 59,4 & Holandia & 60,1 & 62,1 & Rumunia & 57,1 & 58,5 \\
\hline Cypr & 59,2 & 61,3 & Irlandia & 58,3 & 60,6 & Słowacja & 57,0 & 58,7 \\
\hline Czechy & 58,5 & 60,4 & Litwa & 58,1 & 58,7 & Słowenia & 59,3 & 61,7 \\
\hline Dania & 59,9 & 61,3 & Luksemburg & 60,3 & 61,7 & Szwecja & 61,3 & 62,5 \\
\hline Estonia & 57,6 & 59,7 & Łotwa & 57,7 & 59,0 & Węgry & 57,8 & 59,3 \\
\hline Finlandia & 60,6 & 62,5 & Malta & 59,6 & 61,7 & Wielka Brytania & 60,3 & 61,9 \\
\hline Francja & 61,2 & 63,0 & Niemcy & 61,1 & 62,8 & Włochy & 61,9 & $63,4^{1}$ \\
\hline
\end{tabular}

Źródło: opracowanie własne na podstawie danych Eurostat ( ${ }^{1}$ dane z 2008 r.).

W większości zachodnich państw UE wartości postulowanej minimalnej górnej granicy wieku produkcyjnego zaczęły wyraźnie rosnąć w latach 70 . Natomiast w państwach wschodniej części UE wzrost ten rozpoczął się z początkiem lat 90., a nawet kilka lat później, jak w wypadku Rumunii i Bułgarii (por. rysunek 6). Przykładowo w 1980 r. na Malcie górna granica wieku produkcyjnego równa 54,4 roku zapewniała już równość potencjałów życiowych na okres życia w wieku produkcyjnym i nieprodukcyjnym. Najwyższe wartości tego miernika w 1980 r. notowano w Szwecji - 59,2 roku oraz we Włoszech - 58,6 roku. Postulowana minimalna górna granica wieku produkcyjnego dla państw europejskich w ostatnich dziesięcioleciach co roku wzrastała o około 0,2 roku (por. rysunek 6).

W 2009 r. najniższa postulowana minimalna górna granica wieku produkcyjnego wystąpiła w Rumunii, gdzie górna granica wieku produkcyjnego równa 58,5 roku zapewniała równość potencjałów życiowych na okres życia w wieku produkcyjnym i nieprodukcyjnym. Postulowana minimalna górna granica wieku produkcyjnego niższa od 60 lat wystąpiła w 2009 r. także na Słowacji, Litwie, Łotwie, Węgrzech, w Bułgarii, Estonii i w Polsce. Najwyższe wartości wśród państw UE postulowanej minimalnej górnej granicy wieku produkcyjnego wystapiły we Włoszech, gdzie w 2008 r. górna granica wieku produkcyjnego musiałaby być równa 63,4 roku, aby zapewnić równość potencjałów życiowych na okres życia w wieku produkcyjnym i nieprodukcyjnym. Wysokie wartości postulowanej minimalnej górnej granicy wieku produkcyjnego wystąpiły w 2009 r. także w Niemczech, Hiszpanii, Szwecji, Finlandii i we 


\section{Rysunek 5}

Postulowana minimalna górna granica wieku produkcyjnego w 2009 r.

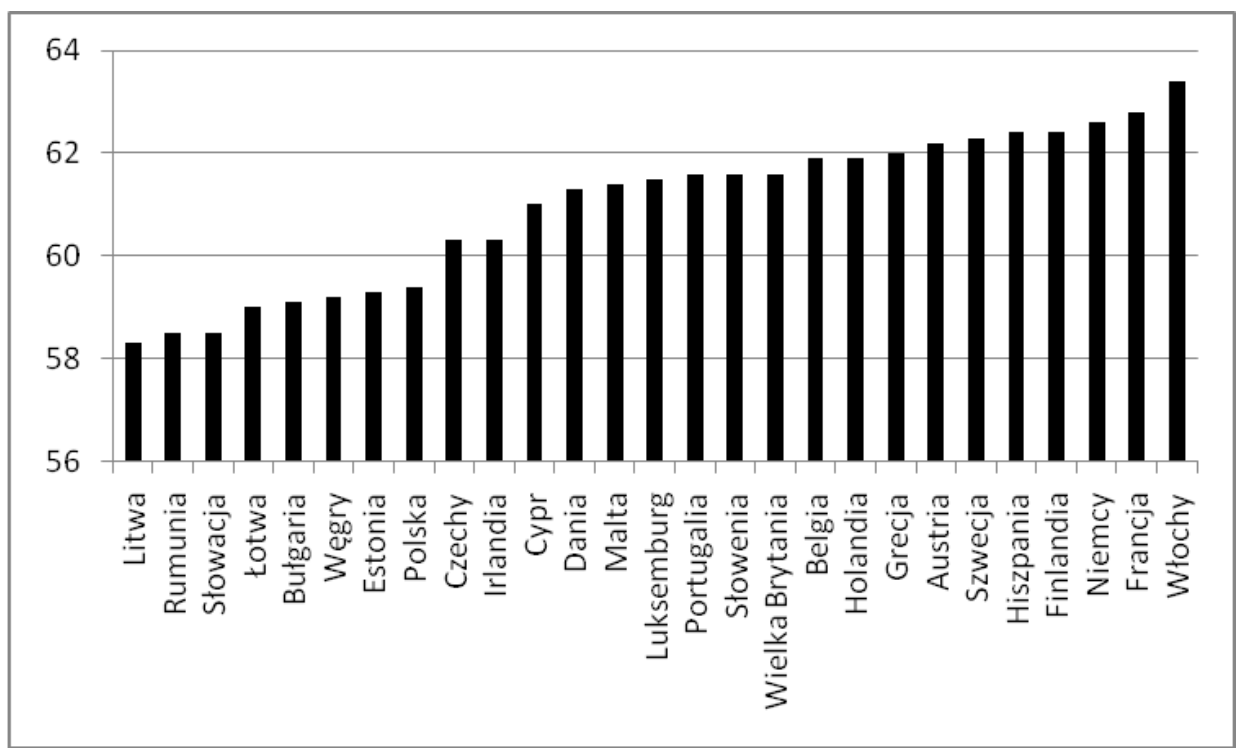

Źródło: opracowanie własne na podstawie danych Eurostat.

\section{Rysunek 6}

Postulowana minimalna górna granica wieku produkcyjnego w wybranych państwach

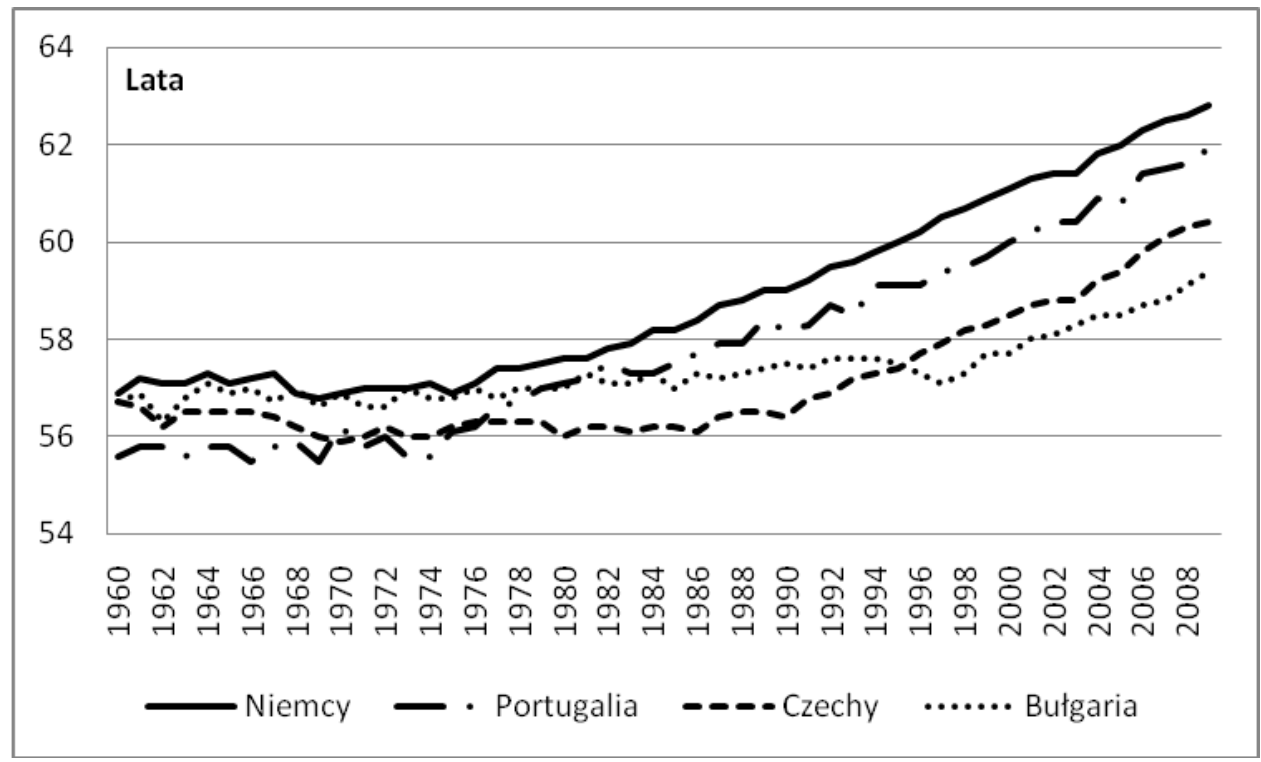

Źródło: opracowanie własne na podstawie danych Eurostat. 


\section{Rysunek 7}

Postulowana minimalna górna granica wieku produkcyjnego w 2009 r.

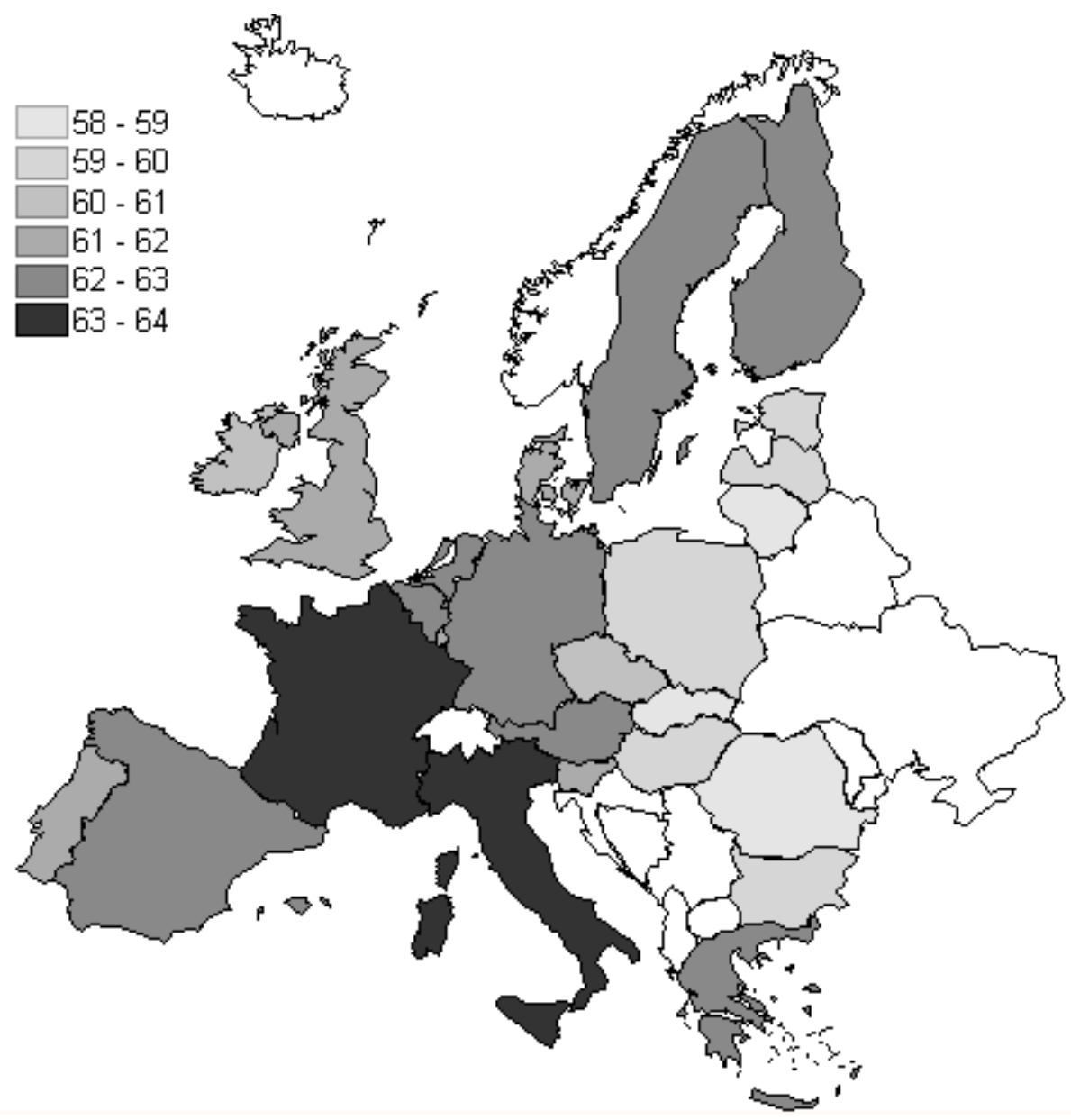

Źródło: opracowanie własne.

Francji. W krajach znajdujących się we wschodniej części Unii Europejskiej wartości postulowanej minimalnej górnej granicy wieku produkcyjnego sa znacznie niższe niż w jej części zachodniej (por. rysunek 7).

Włochy sa państwem, w którym postulowana minimalna górna granica wieku produkcyjnego osiagnęła w 2008 r. 63,4 roku - najwyższą wartość ze wszystkich państw UE - i w ostatnich dwudziestu latach wzrastała przeciętnie o 0,2 roku. Jeżeli to tempo wzrostu utrzyma się to we Włoszech, postulowana minimalna górna granica wieku produkcyjnego osiagnie 65 lat już około $2016 \mathrm{r}$. We Włoskim systemie emerytalnym ustawowo kobiety moga przechodzić na emeryturę w wieku 60 lat, a mężczyźni - 65 lat. Pojawiające się we Włoszech postulaty zrównania wieku emerytalnego kobiet i mężczyzn w świetle otrzy- 
manych wyników postulowanej minimalnej górnej granicy wieku produkcyjnego mogą okazać się już w najbliższym okresie niewystarczające.

W 2009 r. postulowana minimalna górna granica wieku produkcyjnego wynosiła we Francji 63 lata i w ostatnich dziesięciu latach wzrastała rocznie o około 0,2 roku. Można przewidywać, że przekroczy ona 65 lat po 2019 r. Emeryturę we Francji wypłaca się po osiągnięciu wymaganego okresu składkowego bądź po osiągnięciu 65 lat. Minimalny okres składkowy od 2003 r. wynosi we Francji 40 lat i ma wzrosnąc do 41 lat do 2012 r. - co będzie odpowiadać możliwości przejścia na emeryturę najwcześniej około 61 roku życia. Planuje się, że po 2012 r. okres ten będzie wzrastał wraz ze wzrostem przeciętnego dalszego trwania życia ${ }^{5}$.

W 2009 r. postulowana minimalna górna granica wieku produkcyjnego wynosiła w Niemczech 62,8 roku. Można przewidywać, że przekroczy ona 65 lat około 2020 r. W Niemczech ustawowy wiek emerytalny wynosi 65 lat dla kobiet i mężczyzn. Wiek ten zostanie w ciągu najbliższych dwóch dekad podwyższony do 67 lat (dla osób urodzonych w 1964 r. i później) ${ }^{6}$, co w najbliższym okresie pozwoli spełnić postulat, aby ludność Niemiec nie miała więcej lat do przeżycia $\mathrm{w}$ wieku nieprodukcyjnym niż w wieku produkcyjnym.

W 2009 r. postulowana minimalna górna granica wieku produkcyjnego wynosiła w Hiszpanii 62,7 roku. Można oczekiwać, że przekroczy ona 65 roku po $2020 \mathrm{r}$. W wypadku Hiszpanii do osiagnięcia pełnych uprawnień emerytalnych trzeba osiagnąć wiek 65 lat. Aby liczba lat do przeżycia w okresie życia w wieku produkcyjnym nie była krótsza od liczby lat do przeżycia w okresie życia w wieku nieprodukcyjnym, należałoby podwyższyć ustawowy wiek emerytalny dla ludności Hiszpanii najpóźniej około 2020 r.

Kraje skandynawskie UE - Finlandia oraz Szwecja - charakteryzuja się wysokimi wartościami postulowanej minimalnej górnej granicy wieku produkcyjnego. W Finlandii wynosi ona 62,5 roku - i co roku zwiększała się w ostatnim dziesięcioleciu o około 0,2 roku. W obowiązującym systemie emerytalnym w Finlandii emerytura państwowa jest wypłacana po osiąnięciu 65 lat w pełnej wysokości pod warunkiem wykazania czterdziestoletniego okresu rezydencji jako osoby dorosłej. Dodatkowo już po uzyskaniu 62 lat istnieje możliwość przejścia na wcześniejszą emeryturę ${ }^{7}$. Przewiduje się, że około 2022 r. postulowana minimalna górna granica wieku produkcyjnego przekroczy 65 lat, w związku z tym należałoby w najbliższej przyszłości rozpocząć proces stopniowego wydłużania lat aktywności zawodowej przy jednoczesnym ograniczaniu możliwości przechodzenia na wcześniejszą emeryturę. W wypadku Szwecji nie ma ustalonego jednego wieku emerytalnego, jednakże przyjęte rozwiązania pozwalają uznać wiek 65 lat za górna granice wieku produkcyjnego, choć pod pewnymi warunkami istnieje możliwość uzyskania uprawnień emerytalnych już od 61 roku życia ${ }^{8}$. W 2009 r. w Szwecji minimalna postulowana górna granica wieku produkcyjnego wynosiła 62,5 roku, ale

${ }^{5}$ Pensions at a Glance 2011. Retirement-Income Systems in OECD and G20 Countries, OECD, 2011, s. 228.

${ }^{6}$ Ibidem, s. 233

${ }^{7}$ Ibidem, s. 224.

${ }^{8}$ Ibidem, s. 304. 
rocznie zwiększała się tylko o około 0,12 roku. Można przewidywać, że dopiero około 2030 r. minimalna górna granica wieku produkcyjnego osiagnie 65 lat w Szwecji. Przy ograniczeniu możliwości wcześniejszego przechodzenia na emeryturę rozwiązania aktualnie tam obowiązujące moga w świetle otrzymanych wyników okazać się w najbliższym okresie wystarczające.

W Austrii wiek emerytalny dla mężczyzn wynosi 65 lat, natomiast dla kobiet - 60 lat. W 2009 r. w Austrii postulowana minimalna górna granica wieku produkcyjnego wynosiła 62,2 roku i rocznie wzrastała o około 0,18 roku w okresie ostatnich 25 lat. Można przewidywać, że przekroczy ona 65 lat około $2025 \mathrm{r}$. W Austrii planuje się stopniowe podwyższenie wieku emerytalnego kobiet do 65 lat w okresie 2024-2033', jednakże w świetle otrzymanych wyników można uznać, że zrównanie wieku emerytalnego kobiet i mężczyzn nastapi zbyt późno.

W Grecji ustawowy wiek emerytalny wynosi 65 lat, jednakże osoby, które przepracowały 11100 dni (37 lat) mogą przechodzić na emeryturę bez względu na wiek, co oznacza możliwość przejścia na emeryturę najwcześniej już w wieku 57 lat $^{10}$. W Grecji postulowana minimalna górna granica wieku produkcyjnego w 2009 r. wynosiła 62,4 roku i wzrastała co roku w okresie ostatnich 10 lat o około 0,22 roku. Można przewidywać, że przekroczy ona 65 lat około $2022 \mathrm{r}$. W związku z tym należałoby rozpoczać tam stopniowe podwyższenie ustawowego wieku emerytalnego i jednoczesne ograniczenie możliwości przechodzenia na wcześniejszą emeryturę.

W 2009 r. w Holandii górna granica wieku produkcyjnego równa 62,1 roku zapewniłaby równość potencjałów życiowych do przeżycia w okresie życia $\mathrm{w}$ wieku produkcyjnym i nieprodukcyjnym. Rocznie wzrastała ona w okresie ostatnich 10 lat o około 0,23 roku. W Holandii podstawowa emerytura jest płatna od 65 roku życia. Można przewidywać, że postulowana minimalna granica wieku produkcyjnego przy aktualnym tempie wzrostu przekroczy 65 lat po 2022 r., w związku z czym należałoby w przyszłości rozpocząc stopniowe podwyższanie ustawowego wieku emerytalnego.

W Belgii postulowana minimalna górna granica wieku produkcyjnego w 2009 r. wyniosła 62,1 roku (co roku zwiększała się o około 0,16 roku). W wyniku reform od 1 stycznia 2009 r. wiek emerytalny w Belgii wynosi 65 lat zarówno dla kobiet, jak i dla mężczyzn ${ }^{11}$. Można przewidywać, że przy zachowaniu aktualnego tempa wzrostu dopiero na przełomie 2027 i 2028 r. minimalna górna granica wieku produkcyjnego przekroczy tam 65 lat, dlatego rozwiązania aktualnie obowiązujące $\mathrm{w}$ Belgii $\mathrm{w}$ najbliższym okresie moga okazać się wystarczające.

W Wielkiej Brytanii państwowy wiek emerytalny wynosi 65 lat dla mężczyzn i 60 lat dla kobiet, dla których jest od 2010 r. stopniowo podwyższany (docelowo do 65 lat w 2020 r.) ${ }^{12}$. W 2009 r. postulowana minimalna górna

\footnotetext{
9 Ibidem, s. 197.

10 Ibidem, s. 237.

11 Ibidem, s. 200.

12 S. Pieńkowska, Publiczny system emerytalny $w$ Wielkiej Brytanii, ,Polityka Społeczna” 2007, nr 2,
} s. 22 . 
granica wieku produkcyjnego wynosiła 61,9 roku i rocznie zwiększała się w ostatnim dziesięcioleciu średnio o 0,18 roku. Można przewidywać, że w $2020 \mathrm{r}$. wyniesie około 64 lat. Przewiduje się, że postulowana minimalna granica wieku produkcyjnego przekroczy 66 lat po 2030 r. Dlatego zmiany wprowadzone w wyniku ustawy o emeryturach z $2007 \mathrm{r}$. powodujące, że wiek emerytalny wzrośnie do 66 lat pomiędzy 2024 a 2028 r. oraz do 67 lat pomiędzy 2044 a 2046 r. wydają się antycypować przyszłe trendy demograficzne.

Postulowana minimalna górna granica wieku produkcyjnego rocznie zwiększała się dla ludności Słowenii w ostatnich latach aż o 0,26 roku, osiagając w 2009 r. prawie 62 lata. Dla ludności Słowenii ustawowy wiek emerytalny zależy od liczby przepracowanych lat i od płci. W przypadku mężczyzn, którzy potrafia wykazać 15 lat składkowych, wynosi 65 lat, dla 20 lat składkowych -63 lata, dla 40 lat składkowych - 58 lat. W wypadku kobiet, które wykazały tylko 15 lat składkowych, w 2008 r. wynosił 63 lata, dla 20 lat składkowych - 61 lat, dla 36 lat i 9 miesięcy składkowych -56 lat. W wyniku reformy wiek emerytalny kobiet stopniowo rośnie i w 2014 r. wyniesie dla kobiet, które mają 38 lat składkowych -58 lat $^{13}$. Przewiduje się, że około $2022 \mathrm{r}$. postulowana minimalna górna granica wieku produkcyjnego osiagnie 65 lat - dlatego należałoby w najbliższym okresie rozważyć wprowadzenie tam wieku emerytalnego równego co najmniej 65 lat dla kobiet i mężczyzn, bez względu na długość okresu składkowego, a w dalszej perspektywie rozpocząć proces stopniowego podwyższania ustawowego wieku emerytalnego.

W Portugalii postulowana minimalna górna granica wieku produkcyjnego w 2009 r. wynosiła 61,9 roku i w ostatnim dziesięcioleciu wzrastała rocznie o około 0,21 roku. Dla mieszkańców Portugalii standardowy wiek emerytalny wynosi 65 lat, jednakże istnieje możliwość wcześniejszego przejścia na emeryturę już od 55 roku życia przy 30 latach składkowych ${ }^{14}$. Przewiduje się, że po 2024 r. postulowana minimalna górna granica wieku produkcyjnego przekroczy 65 lat. W najbliższym okresie należałoby przede wszystkim ograniczyć możliwość wcześniejszego przechodzenia na emeryturę, a później rozpocząć stopniowe podwyższanie ustawowego wieku emerytalnego.

Dla ludności Luksemburga postulowana minimalna górna granica wieku produkcyjnego w 2009 r. wyniosła 61,7 roku i w ciagu ostatnich 30 lat wzrastała co roku przeciętnie o około 0,14 roku. W Luksemburgu standardowy wiek emerytalny wynosi 65 lat, ale istnieje możliwość przedłużenia wieku przejścia na emeryturę do 68 lat. Istnieją również rozwiązania pozwalające, pod warunkiem finansowania przez 40 lat składek emerytalnych, przejść na emeryturę już w wieku 57 lat. Do przejścia na wcześniejsza emeryturę w wieku 60 lat wymagany jest już tylko dziesięcioletni okres finansowania składek emerytalnych ${ }^{15}$. Przewiduje się, że dopiero po 2030 r. postulowana minimalna górna granica wieku produkcyjnego przekroczy 65 lat. W związku z tym w najbliższym okresie nie powinny być konieczne radykalne zmiany w systemie emerytalnym,

\footnotetext{
${ }^{13}$ Pensions at a Glance..., s. 297.

14 Ibidem, s. 287.

15 J. Poteraj, System emerytalny w Luksemburgu, „Polityka Społeczna” 2009, nr 4, s. 26-27.
} 
a wprowadzone w 2002 r. działania reformatorskie zachęcające do późniejszego przechodzenia na emeryturę powinny okazać się wystarczające.

$\mathrm{Na}$ Malcie postulowana minimalna górna granica wieku produkcyjnego w 2009 r. wyniosła 61,7 roku i w ciągu ostatnich 10 lat co roku zwiększała się o 0,23 roku. Na Malcie wiek emerytalny wynosi 61 lat dla mężczyzn i 60 lat dla kobiet i jest podnoszony według daty urodzenia, to jest na przykład dla osób urodzonych po $1961 \mathrm{r}$. będzie wynosił 65 lat $^{16}$. Przewiduje się, że po $2023 \mathrm{r}$. postulowana minimalna górna granica wieku produkcyjnego przekroczy 65 lat, dlatego stopniowe podwyższanie wieku emerytalnego w późniejszym okresie powinno być kontynuowane.

W Danii postulowana minimalna górna granica wieku produkcyjnego w 2009 r. wyniosła 61,3 roku i w czasie ostatnich 20 lat rocznie wzrastała o około 0,17 roku. W Danii standardowy wiek emerytalny wynosi 65 lat, a w latach 2024-2027 planuje się jego stopniowe podwyższenie do 67 lat $^{17}$. Przewiduje się, że dopiero po 2030 r. postulowana minimalna górna granica wieku produkcyjnego przekroczy 65 lat, dlatego aktualne i planowane rozwiązania dotyczące wieku przechodzenia na emeryturę okażą się w przyszłości wystarczające.

$\mathrm{Na}$ Cyprze postulowana minimalna górna granica wieku produkcyjnego w 2009 r. wyniosła 61,3 roku. Na Cyprze zarówno dla kobiet, jak i dla mężczyzn ustawowy wiek emerytalny wynosi 65 lat. Przewiduje się, że dopiero na przełomie 2027 i 2028 r. postulowana minimalna górna granica wieku produkcyjnego przekroczy tam 65 lat, w związku z tym w najbliższym okresie podwyższenie wieku emerytalnego nie będzie konieczne.

Dla ludności Irlandii postulowana minimalna górna granica wieku produkcyjnego w 2009 r. wyniosła 60,6 roku. Irlandczycy moga przechodzić na emeryturę w wieku 65 lat. Przewiduje się, że dopiero około 2027 r. postulowana minimalna górna granica wieku produkcyjnego przekroczy 65 lat, w związku z tym w najbliższym okresie podwyższenie wieku emerytalnego nie będzie konieczne.

W Czechach postulowana minimalna górna granica wieku produkcyjnego w 2009 r. wyniosła 60,4 roku i była najwyższa wśród byłych państw socjalistycznych. W Czechach standardowy wiek emerytalny ma wzrosnąc do 65 lat dla mężczyzn (w 2010 r. było to 61 lat), natomiast w przypadku kobiet ma się kształtować od 62 do 65 lat w zależności od liczby wychowanych dzieci ${ }^{18}$. Przewiduje się, że dopiero po 2030 r. postulowana minimalna górna granica wieku produkcyjnego przekroczy 65 lat, dlatego planowane reformy emerytalne w najbliższym okresie okażą się wystarczające.

W Polsce postulowana minimalna górna granica wieku produkcyjnego w 2009 r. wyniosła 59,5 roku i w okresie ostatnich 20 lat rocznie zwiększała się o 0,18 roku. W Polsce minimalny wiek emerytalny wynosi 60 lat dla kobiet i 65 2008

${ }^{16}$ B. Kłos, Wiek emerytalny kobiet $i$ mężczyzn, Biuro Analiz Sejmowych, indos nr 3 (27), Warszawa

17 Pensions at a Glance..., s. 216.

${ }^{18}$ Ibidem, op. cit., s. 212. 
dla mężczyzn, a aktualnie toczy się dyskusja na temat podwyższenia wieku emerytalnego dla kobiet i mężczyzn, docelowo do 67 lat do 2040 r. dla kobiet oraz do 2020 r. dla mężczyzn. Przewiduje się, że dopiero po 2030 r. postulowana minimalna górna granica wieku produkcyjnego przekroczy 64 lata, dlatego $\mathrm{w}$ najbliższym okresie wystarczy zrównanie wieku emerytalnego kobiet i mężczyzn na poziomie 65 lat, natomiast tak szybkie podwyższanie wieku emerytalnego dla mężczyzn nie jest konieczne.

W Estonii postulowana minimalna górna granica wieku produkcyjnego w 2009 r. wyniosła 59,7 roku i w okresie ostatnich 10 lat co roku wzrastała o około 0,22 roku. Dla ludności Estonii ustawowy wiek emerytalny wynosi 63 lata dla mężczyzn, a dla kobiet w 2016 r. również osiagnnie wiek 63 lat $^{19}$. Przewiduje się, że dopiero pod koniec 2030 r. postulowana minimalna górna granica wieku produkcyjnego przekroczy 64 lata, w związku z tym w świetle otrzymanych wyników w najbliższej przyszłości radykalne zmiany ustawowego wieku przejścia na emeryturę nie będą konieczne.

Na Węgrzech postulowana minimalna górna granica wieku produkcyjnego w 2009 r. wyniosła 59,3 roku i podczas ostatnich 20 lat rocznie zwiększała się o 0,17 roku. Na Węgrzech wiek emerytalny wzrósł w ostatnim okresie do 62 lat dla mężczyzn i kobiet i ma być stopniowo podwyższany do 65 lat w $2022 \mathrm{r}^{20}$ Przewiduje się, że w 2022 r. postulowana minimalna górna granica wieku produkcyjnego będzie wynosić około 61,5 roku, dlatego planowane rozwiązania emerytalne okażą się w najbliższym okresie wystarczające.

W Bułgarii postulowana minimalna górna granica wieku produkcyjnego w 2009 r. wyniosła 59,4 roku i w okresie ostatnich 15 lat co roku wzrastała o około 0,17 roku. Reforma emerytalna z 2000 r. podnosiła stopniowo dla ludności Bułgarii ustawowy wiek emerytalny kobiet z 55 lat do 60 lat i mężczyzn z 60 lat do 63 lat $^{21}$. Przewiduje się, że dopiero po 2030 r. postulowana minimalna górna granica wieku produkcyjnego przekroczy 63 lata. W związku z tym należałoby w dalszej kolejności doprowadzić do wyrównania wieku emerytalnego kobiet i mężczyzn.

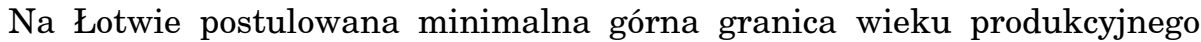
w 2009 r. wyniosła tylko 59 lat, choć w okresie ostatnich kilku lat zwiększała się o około 0,3 roku. Na Łotwie ustawowy wiek emerytalny wynosi zarówno 62 lata dla mężczyzn oraz dla kobiet. Jeżeli zaobserwowane w okresie ostatnich kilku lat tempo wzrostu postulowanej minimalnej górnej granicy wieku produkcyjnego utrzyma się to należałoby rozpoczać w najbliższej przyszłości stopniowe podwyższanie wieku emerytalnego dla ludności.

Dla ludności Słowacji postulowana minimalna górna granica wieku produkcyjnego w $2009 \mathrm{r}$. wyniosła tylko 58,7 roku i w okresie ostatnich 10 lat co roku zwiększała się o około 0,17 roku. Na Słowacji nastąpił proces wyrównywania wieku emerytalnego kobiet i mężczyzn. Wiek emerytalny dla mężczyzn od 2006 r. wynosi 62 lata, natomiast dla kobiet jest podwyższany stopniowo

\footnotetext{
19 B. Kłos, op. cit.

${ }^{20}$ Pensions at a Glance..., s. 241.

${ }^{21}$ J. Poteraj, System emerytalny w Butgarii, „Polityka Społeczna” 2007, nr 9, s. 17.
} 
i będzie wynosić 62 lata w 2014 r. ${ }^{22}$ Postulowana minimalna górna granica wieku produkcyjnego dla ludności Słowacji zaczęła rosnać dopiero od początku lat 90. ubiegłego wieku. Przewiduje się, że dopiero około 2028 r. przekroczy ona 62 lata, dlatego aktualne rozwiązania emerytalne w najbliższym okresie okażą się wystarczające.

W Rumunii postulowana minimalna górna granica wieku produkcyjnego w 2009 r. wyniosła 58,5 roku i w okresie ostatnich 10 lat co roku zwiększała się o około 0,18 roku. W przypadku Rumunii wiek emerytalny jest podnoszony stopniowo od 2000 r. i ma docelowo wynieść w 2014 r. 60 dla kobiet i 65 dla mężczyzn ${ }^{23}$. Przewiduje się, że dopiero około 2029 r. postulowana minimalna górna granica wieku produkcyjnego przekroczy 62 lata, w związku z tym po 2014 r. należałoby w dalszej kolejności kontynuować proces podwyższania wieku emerytalnego dla kobiet i docelowo zrównać go z wiekiem mężczyzn.

Dla mieszkańców Litwy postulowana minimalna górna granica wieku produkcyjnego w 2009 r. wyniosła 58,7 roku i dopiero w ostatnich kilku latach zaczęła wykazywać trend rosnący. Na Litwie ustawowy wiek emerytalny wynosi 62,5 roku dla mężczyzn oraz 60 lat dla kobiet. Wydaje się, że z punktu widzenia postulatu, aby populacja nie miała więcej lat do przeżycia w okresie życia $\mathrm{w}$ wieku nieprodukcyjnym niż $\mathrm{w}$ okresie życia $\mathrm{w}$ wieku produkcyjnym, $\mathrm{w}$ najbliższym okresie wystarczy w litewskim systemie emerytalnym tylko rozpocząc stopniowe wyrównywanie wieku emerytalnego kobiet i mężczyzn.

\section{ZAKOŃCZENIE}

W artykule porównano dla państw UE wyniki zaproponowanej przez autora metody pozwalającej wyznaczyć górną granicę wieku produkcyjnego, dla którego liczba lat do przeżycia $\mathrm{w}$ wieku produkcyjnym byłaby równa liczbie lat do przeżycia w wieku nieprodukcyjnym. Zakładając, że ludność nie powinna mieć do przeżycia więcej lat $\mathrm{w}$ wieku nieprodukcyjnym niż $\mathrm{w}$ wieku produkcyjnym, tak wyznaczony wiek można uznać za postulowaną minimalną górna granicę wieku, po którym powinno się przechodzić na emeryturę. Porównując wyniki z rozwiązaniami obwiązującymi w systemach emerytalnych funkcjonujących w danym państwie, można stwierdzić, czy dane rozwiązania są lub będą w najbliższej przyszłości wystarczające. Najwyższe wartości wskaźnika wystapiły w takich krajach, jak Włochy, Francja i Niemcy, natomiast najniższe w krajach bałtyckich oraz w Rumunii i na Słowacji.

mgr Radostaw Murkowski

Uniwersytet Ekonomiczny w Poznaniu

r.murkowski@ue.poznan.pl

${ }^{22}$ Pensions at a Glance, op. cit., s. 293.

${ }^{23}$ B. Kłos, op. cit. 


\section{PENSION AGE IN THE EUROPEAN UNION IN THE CONTEXT OF AGE DEPENDENCY RATIO AND LIFE EXPECTANCY}

\section{Summary}

The author proposes a technique of calculating the postulated minimum upper limit of the productive age, which uses potential demography methods. The technique is based on the postulate that the total number of years to live after the productive age for the whole population should not be higher than the total years to live in the productive age. This method accounts for both the length of the life expectancy and the population age structure. The minimum upper limit of the productive age is the highest for the population with a long life expectancy and high age dependency ratio. The results obtained using this technique for calculations in all European Union member states were compared and related to the statutory pension ages. 